\title{
Measuring Customer Satisfaction towards Cafeteria Services in Primary Health Care Setting: A Cross-Section Study among Patients and Health Care Providers in Bintulu, Sarawak
}

\author{
Kong Jian Pei ${ }^{1}$, Azlee Bin Ayub ${ }^{2}$ \\ ${ }^{1}$ Dietitian, Dietetic Services of Outpatient Department, Pejabat Kesihatan Bahagian Bintulu (Government \\ Primary Referral Polycinic of Bintulu), Bintulu, Malaysia \\ ${ }^{2}$ Division of Health Officer (DHO), Pejabat Kesihatan Bahagian Bintulu, Bintulu, Malaysia \\ Email: johnkong1988@gmail.com
}

Received 14 March 2015; accepted 29 March 2015; published 3 April 2015

Copyright (C) 2015 by authors and OALib.

This work is licensed under the Creative Commons Attribution International License (CC BY). http://creativecommons.org/licenses/by/4.0/

(c) (i) Open Access

\section{Abstract}

In Malaysia, the total number of patients accessing primary health care institution increased from 137,604 in 2008 to 141,593 in 2012. Tremendously large numbers of patients on primary health care institution have unquestionably raised the expansion of demand for food service availability and quality on institution. The objective of this study was to determine the levels of satisfaction (food quality, service quality, ambience, price and portion) among patients and staffs on the cafeteria facilities in Klinik Kesihatan Bintulu, Sarawak. A self-reported questionnaire was administered to 256 subjects at Polyclinic Bintulu from May to August in 2014. The findings showed that all four attributes turn out to be the dissatisfied attributes among staffs; in contrast, patients incline towards satisfaction on the attributes of food, service and ambience quality. Staffs and patients showed significant difference $(p<0.0)$ on the satisfaction level towards the three attributes of food, services and ambience quality. Although both groups dissatisfied toward the price and portion attributes, the dissatisfaction toward food service operator among staffs $(M=2.05)$ was significantly higher $(p<0.0)$ when comparing with patients $(M=2.40)$. Respondents believed that introducing menu of the day and increasing menu variation were the two supplementary factors that may increase satisfaction level.

\section{Keywords}

Client Satisfaction, Primary Health Care

Subject Areas: Operations Management, Organizational Behavior, Production/Operations

How to cite this paper: Pei, K.J. and Ayub, A.B. (2015) Measuring Customer Satisfaction towards Cafeteria Services in Primary Health Care Setting: A Cross-Section Study among Patients and Health Care Providers in Bintulu, Sarawak. Open Access Library Journal, 2: e1361. http://dx.doi.org/10.4236/oalib.1101361 


\section{Management}

\section{Introduction}

In its race against the clock to achieve its goal of becoming an innovation-based economy nation by the year 2020, the government has set aside a large chunk of its budget to promote primary health care system to ensure the quality of life of our nation. According to National Medical Care Survey [1], a provider-based survey, the number of patients enrolling to primary health care establishment increased from 137,604 in 2008 to 141,593 in 2012. The report highlighted that out of 233,326 recorded as reasons for encounter (RFEs) in public clinic, cases which were related to nutritional problem were quite common; for example, for every 100 patients, 33 had the diagnosis of hypertension, followed by lipid disorder (22 per 100 encounters), and diabetes (24 per 100 encounter). Therefore, food service operator established in a primary health care unit became extremely important as most of the time patients would rely on the cafeteria from the primary health care setting to achieve their nutritional requirement especially for those regular follow-up patients as well as permanent health care staffs. During the recent recession, the government has allocated RM26bil over the 10th Malaysia Plan period to further increase the number of polyclinic in Sarawak to better serve the residents there; Prime Minister Datuk Seri Najib Tun Razak has also announced that "The Health Ministry will build another 50 Malaysia Clinics nationwide, and for next year, we will be launching 25 and so, we are considering one in Sibu”, noting that Sarawak Minister of Environment and Public Health-Dato Sri Wong Soon Koh and SMC works and traffic standing committee chairman-Robert Lau Hui Yew had made requests to increase the number of Malaysia clinics in Sibu [2].

In view of that, the high demand for primary health care establishment in Malaysia indirectly would ensure the expansion of demand for food service availability and quality on the establishment itself, as well as for the staff, visitors and patients. Today, a primary health care food service has unquestionably become a big market today, competing within not only local and private food service operators but also fast foods, vending machines, etc. [3]. With that, today's customers are no longer tolerating poor quality of food served by respective dining facility but expecting more than good food quality and nutritional value of the food they consume [4], as food is a substance taken into the body to sustain life, furnish energy and promote growth. According to Drummond [5], nutritious food has become extremely important when it comes into a vulnerable consumer especially target population like patients and persons who are under a immunocompromised environment, as it helps them to stay alert, feel comfortable and keep optimal status in their health and gradually in improving their quality of life. Therefore, it is important for food service operators to fully recognize the wants of patients and health care providers, and meet their needs in order to keep up with the growing expectations of patients and staffs about the overall institution dining experiences.

Customer satisfaction is often used to predict the likelihood of customers returning to a restaurant [6]. Some studies [7] [8] have shown that customer satisfaction is important to food service managers because it leads to repeat patronage, brand loyalty, and new customers through word-of mouth promotion. Despite notable progress in customer satisfaction research in hospitality or restaurant industry [7] [8], customer satisfaction in the government institution especially primary health care industry has remained under-researched, especially in Malaysia. Nevertheless, a recent study [6] showed that Institutional DINESERV Dimensions had a significant positive effect on overall customer in relation to a positive effect on overall customer satisfaction and revisit intention. Improving customer satisfaction, which results in increased return intention and positive word-of-mouth endorsement will in turn not only strengthen customer loyalty, but also improve the dining facility's reputation and generate greater revenue [6]. Therefore, our study would adopt this simple and reliable concept approach in determining how consumers perceived a dining's quality. By following the concept of DINESERV [6], a food operator is able to identify how students view the dining's quality, where problems are and get a clue on solution. Among total 18 possible variance of customer satisfaction in university foodservice setting, the most powerful predictor of student satisfaction was food quality, service quality, ambience, convenience and price. These 4 factors explained $77.22 \%$ of the total variance tested in the author study. The communality of each variable was relatively high, ranging from 0.56 to 0.89 . Therefore, all these four most relevant university foodservice attributes were used as a framework in assessing the customers satisfaction toward cafeteria's facilities in our study; however, considering the relevant applicability to our campus study: the convenience element has grouped under the "ambiance elements" and portion size variables was grouped under price element to reflect "dissatisfied with what they get for what they give" [3]. 
In the past few decades, studies showed that many of the branding food service operations have been successfully adapted by hospital operation such as Taco Bell, Burger King, Kentucky Fried chicken, Starbucks Coffee, Crispy Cream Donuts and Subway due to changing of patients and staffs trend, also population which are demanding of more upgraded food service quality, and desired menu, and awareness of nutrition [9]. In addition, many of the other foodservices are constantly renovating or upgrading their dining facilities by following the patients and staffs' expectation and demand [10]. Thus, these three supplementary variables (franchise outlet, special menu, increasing of menu option) were incorporated as part of this study to identify if any one of these key cues could increase customer satisfaction, particular in Malaysia's primary health care establishments.

Cafeteria service at Polyclinic Bintulu had been established in 2012. The cafeteria was located at Ground Level in Polyclinic Bintulu. The cafeteria was operated by one contracted food service providers namely "WAWA Enterprise" which was also the only food service provider since 2013 to cater for 250 staffs and 548 patients per day. According to the registration counter, the average of the number of patients attended the outpatient clinic has increased from 471 at 2011 to 548 patients 2014. The current food services systems used were ready-prepared food service operation system. Generally, the cafeteria should operate about eight operating hours starting from 7.30 a.m. till 5.00 p.m. every day except weekends which were non-operating hours.

However, based on a few complaints [11] filed in Pejabat Kesihatan Bintulu, it revealed that majority of the complaint received were uncomfortable about the operation hour as the closing hours could be as early as 3.30 p.m., in fact, some the longest record of non-operating days were around 5 days and most of them were without giving any announcement to the patients and staffs. Indeed, the presence food service providers admitted that their closing hours are actually depending on the availability of foods and the presence of staffs and patients.

As the only food service provider, the cafeteria provided foods and beverage to more than 700 - 850 staffs and patients daily. A variety of foods and beverages are sold at the cafeteria including various rice and noodle, fruits, drinks and snacks. However, it was worth pointing out that most of the foods sold were ready-to-eat. Therefore, patients and staffs were not able to enjoy cook-to-served food [11]. In addition, there were complaints found that the portion of food was not reasonable with the price listed. Nevertheless, the food service providers did not response regard to the complaints filed under the management level.

Besides, some staffs had displeasure on cafeteria space and facilities mainly because of limited tables and chairs [11]. These occurrences could be related to the inability of the operators in providing variety type of cuisine and good dining experience which probably lead to complaints found frequently.

Above all, the author believes that these issues will definitely result in serious consequences to the staffs and patients in Polyclinic Bintulu and the operators. With that, this study empirically assess satisfaction level on all four different attributes at Klinik Kesihatan Bintulu's cafeterias by administering the questionnaire based on the theoretical framework of Institutional DINESERV (food quality, service quality, ambience, and price \& portion).

\section{Methodology}

The structure of the methodology is arranged as follows: first we look for an appropriate study design and target population based on our general objective of this study which focused on the overall satisfaction level at Kilnik Kesihatan Bintulu's cafeterias; then we design a questionnaire corresponding to the study objective based on a few validated questionnaire, back-to-back translation and reliability of the questionnaire was determine after the pilot test conducted at similar setting which was Hospital Bintulu. Finally, we establish the conclusion based on our analysed and interpreted result, as well as bring forward some research solution and limitations.

\subsection{Study Design and Subjects}

This study was a cross sectional study. A self-reported experience through a questionnaire survey was developed to obtain the required data. The target population of staffs and patients from Polyclinic Bintulu each was 128 subjects. The minimum participants required in order for the study to be representative of the postgraduate students population was calculated, with the significance level at $5 \%$ and degree of accuracy at $5 \%$. Using the formula [12] by Krejcie \& Morgan (1970), the number of estimated participants from each group calculated were 128 which also considered $10 \%$ of dropout. Total of the participants were 256.

$$
n=\frac{X^{2} N P(1-P)}{\Delta^{2}(N-1)+X^{2} P(1-P)}
$$

(Krejcie \& Morgan, 1970). 


\subsection{Reliability}

The initial Cronbach's alpha of the questionnaire was 0.558. Nunnally (1978) [13] recommends that instruments used in basic research have reliability of about 0.70 or better. Thus, two questions were deleted from the questionnaire in order to increase the Cronbach's alpha of the questionnaire to 0.75 .

\subsection{Data Collection}

The questionnaire was first piloted with 50 staffs and 50 patients from Hospital Bintulu. Respondents were approached and were informed that all information provided would be kept private and confidential. The questionnaires were then distributed to the respondents in Polyclinic Bintulu who agreed to participate in the study. The nature and requirement of the survey was briefly explained before the respondents fill in the questionnaire based on their experience on using the cafeteria facilities. Patients was assisted by inspectorate officer while filling in the questionnaire.

\subsection{Statistical Analysis}

Statistical Package for the Social Sciences Window Version 20.0 (SPSS) program was used to analyze the data collected. Descriptive statistic (e.g. mean and percentage) and statistical test such as independent T-test was used in order that the study's objective would be met.

\section{Results}

A total of 256 participants out of participated in this study, indicating a response rate of $85 \%$. Staffs and patients, each was stand for $50 \%(n=128)$ from the total of 256 subjects. Table 1 summarised the results with regard to socio-demographic characteristic of all the recruited participants. About 95 subjects were male (37\%) and 161 were female (63\%). All of them were aged between 18 - 68 years old and the mean age was $32.81 \pm 10.9$. Among the whole study population, about 55 of them were Malay (22\%), 32 were Chinese (13\%), 112 was Iban (44\%), 16 was Bidayuh (6.3\%) and the remaining 41 were others (16\%). Majority of the study population were from government servant (64\%), followed by private sector (17\%), self-employed (11\%) and others (5.9\%). The income status from the total of 185 participants demonstrated that majority (51\%) of the participants came from low income family background, followed by moderately high (18\%), only 3.1\% of them from affluent family background. Mean and standard deviation of monthly feeding budget were RM $453.5 \pm 304.10$ to be specific. Most of participants achieved secondary level of education (43.0\%), followed by college (28.9\%), universities (12.9\%), with a minority of $9 \%$ and $7 \%$ were illiterate and achieved primary school at least. Descriptive statistics were employed to look at the mean scores in order to identify the satisfaction level on the food attributes. Table 2 revealed four items analyzed under the attributes of food quality, food cleanliness was the most satisfied attribute $(M=2.57)$, followed by freshness $(M=2.39)$, food texture $(M=2.38)$ and food temperature $(M=$ 2.34). Generally, nearly all score below 2.5 except attribute of food quality.

For the service quality provided by the cafeteria, Table 3 indicated the mean score of availability of eating utensils was poorest $(M=2.45)$, followed by Staffs' friendliness $(M=2.45)$, and efficiency of food preparation $(\mathrm{M}=2.49)$. On the other hand, the mean score of sufficiency of eating utensils marked the highest score $(\mathrm{M}=$ 2.57) compared with the score of staffs' hygiene $(M=2.51)$. Four items were used to assess the respondents' view related to ambience attribute (Table 4). Majority of the respondents expressed their dissatisfaction towards the least satisfied with the hand wash facilities (hand basin, fan, light, and hand dryer) provided $(\mathrm{M}=2.35$ ), level of comfort at the dining area $(M=2.44)$, followed by dining space arrangement $(M=2.44)$. However, the respondents the location of dining area is convenience $(M=2.63)$. Table 5 showed two items tested under price and portion attributes, the mean score of food portion $(M=2.20)$ and price $(M=2.25)$ explained that majority of the respondents were dissatisfied with this attributes. Next, Table 6 revealed that staffs $(\mathrm{M}=2.20, \mathrm{M}=2.32, \mathrm{M}=$ 2.33) were dissatisfied with the entire attribute provided by the current tenant (Food, Service, Ambience) compared to patients ( $\mathrm{M}=2.63, \mathrm{M}=2.67, \mathrm{M}=2.61, \mathrm{M}=2.40)$ which showed mostly as satisfaction to nearly all attributes. However, both groups share a common factor that both were not satisfied with price and portion attributes (Staffs 2.05, Price and Portion 2.40). The independent $\mathrm{T}$ test showed that the satisfaction level was significant difference between both groups on each category of attributes $(\mathrm{p}<0.05)$ (Hypothesis: there will be no significant difference on satisfaction level between patients and staffs on each category of food service 
Table 1. Demographic characteristics of participants.

\begin{tabular}{|c|c|c|}
\hline Variables & Frequency (n) & Percentage (\%) \\
\hline \multicolumn{3}{|l|}{ Gender } \\
\hline Male & 95 & 37 \\
\hline Female & 161 & 63 \\
\hline \multicolumn{3}{|l|}{ Respondent } \\
\hline Staffs & 128 & 50 \\
\hline Patients & 128 & 50 \\
\hline Age $^{*}$ & 226 & $32.8(10.9)^{*}$ \\
\hline \multicolumn{3}{|l|}{ Ethnicity } \\
\hline Malay & 55 & 46 \\
\hline Chinese & 32 & 42 \\
\hline Iban & 112 & 2 \\
\hline Bidayuh & 16 & 6.3 \\
\hline Others & 41 & 16 \\
\hline \multicolumn{3}{|l|}{ Occupation Sector } \\
\hline Private sector & 43 & 16.8 \\
\hline Government sector & 164 & 64.1 \\
\hline Self-employed & 28 & 10.9 \\
\hline Others & 15 & 5.9 \\
\hline \multicolumn{3}{|l|}{ Education Level } \\
\hline No schooling & 22 & 8.6 \\
\hline Primary school & 17 & 6.6 \\
\hline Secondary school & 110 & 43.0 \\
\hline College & 74 & 28.9 \\
\hline University & 33 & 12.9 \\
\hline \multicolumn{3}{|l|}{ Monthly Income (RM) } \\
\hline$<2300$ & 130 & 50.8 \\
\hline$<2300-5599$ & 46 & 18.0 \\
\hline$<5560$ & 8 & 3.1 \\
\hline Feeding Budget (RM)* & 40 & $453.5(304.1)^{*}$ \\
\hline
\end{tabular}

${ }^{*}$ Mean \pm SD.

Table 2. Mean score for food quality attributes.

\begin{tabular}{cccc}
\hline & Attributes & Mean & SD \\
\hline $\mathbf{1}$ & Food freshness $(\mathrm{n}=251)$ & 2.39 & 0.79 \\
$\mathbf{2}$ & Food texture $(\mathrm{n}=250)$ & 2.38 & 0.76 \\
$\mathbf{3}$ & Food temperature $(\mathrm{n}=252)$ & 2.34 & 0.81 \\
$\mathbf{4}$ & Food cleanliness $(\mathrm{n}=254)$ & 2.57 & 0.77 \\
\hline
\end{tabular}


Table 3. Mean score for service quality attributes.

\begin{tabular}{cccc}
\hline & Attributes & Mean & SD \\
\hline $\mathbf{1}$ & Eating utensils' cleanliness $(\mathrm{n}=253)$ & 2.45 & 0.79 \\
$\mathbf{2}$ & Staffs' hygiene $(\mathrm{n}=251)$ & 2.51 & 0.72 \\
$\mathbf{3}$ & Sufficiency of eating utensils $(\mathrm{n}=248)$ & 2.57 & 0.74 \\
$\mathbf{4}$ & Staffs' friendliness $(\mathrm{n}=249)$ & 2.45 & 0.80 \\
$\mathbf{5}$ & Food preparation efficiency $(\mathrm{n}=249)$ & 2.49 & 0.84 \\
\hline
\end{tabular}

Table 4. Mean score for ambience attributes.

\begin{tabular}{|c|c|c|c|}
\hline & Attributes & Mean & SD \\
\hline 1 & Convenient location $(n=246)$ & 2.63 & 0.84 \\
\hline 2 & Dining space arrangement $(n=247)$ & 2.44 & 0.79 \\
\hline 3 & Facilities (hand basin, fan, light, hand dryer) $(n=241)$ & 2.35 & 0.81 \\
\hline 4 & Comfort of the dining area $(n=241)$ & 2.44 & 0.81 \\
\hline
\end{tabular}

Table 5. Mean score for price and portion attributes.

\begin{tabular}{cccc}
\hline & Attributes & Mean & SD \\
\hline $\mathbf{1}$ & Food portion $(\mathrm{n}=256)$ & 2.20 & 0.72 \\
$\mathbf{2}$ & Price $(\mathrm{n}=256)$ & 2.25 & 0.76 \\
\hline
\end{tabular}

Table 6. Satisfaction level by races.

\begin{tabular}{ccccc}
\hline \multirow{2}{*}{ Attributes } & Staff & Patients & \multirow{2}{*}{ t statistic (df) } & p value \\
\cline { 2 - 3 } & Mean (SD) & Mean (SD) & & 0.0 \\
Food Quality & $2.20(0.62)$ & $2.63(0.67)$ & $-5.329(252)$ & 0.0 \\
Services Quality & $2.32(0.57)$ & $2.67(0.65)$ & $-4.594(251)$ & 0.0 \\
Ambience Quality & $2.33(0.61)$ & $2.61(0.67)$ & $-3.586(247)$ & 0.0 \\
Price and Portion & $2.05(0.60)$ & $2.40(0.58)$ & $-4.695(254)$ & 0.0 \\
\hline
\end{tabular}

Tested at $\mathrm{p}<0.05$, using independent sample $\mathrm{T}$ test.

attributes). The results from Table 7 showed that introducing menu of the day was the most preferred choice of participants (61\%), followed by increasing menu variation (29\%), and introducing franchise outlet (48\%).

\section{Discussion}

This study found that participant was not satisfied $(M \leq 2.5)$ with nearly all the attributes from food quality except food cleanliness. Author believe the most likely reason is because all the food and beverage preparation process are basically done on the day before operation, and despite there were ala carte menu such as Chicken Rice and Nasi Lemak, these menus are not prepared upon ordering, instead pack using transparent plastic, thus the food freshness, texture, and temperature cannot be guaranteed. Study from both fast food [14] and Chinese restaurant [15] studies indicated which food quality was rated as one of the most significant contributing factor of a customer's intention to revisit, also Mattila (2001)'s study [16] also reaffirmed that food quality was the most significant reason for customer to revisit a casual-dining facilities. Similar notion was also indicated in the study of Kim (2005) [17] that the taste, freshness and nutrition content of food were the key to achieve customer satisfaction and improve intention to return, Next, another noteworthy finding was that respondents were most dissatisfied on the temperature of the food $(M=2.34)$ compare with other element under this category. It could 
Table 7. Supplementary factors.

\begin{tabular}{cccc}
\hline Supplementary factors & Yes (\%) & No (\%) & No response (\%) \\
\hline Introduce franchise outlet $(\mathrm{n}=256)$ & 25 & 75 & 39 \\
Introduce menu of the day $(\mathrm{n}=256)$ & 61 & 71 & 100 \\
Increase menu variation $(\mathrm{n}=256)$ & 29 & 99.6 \\
\hline
\end{tabular}

be due to lack of bain marrie to keep materials warm over a period of time. Namkung et al. (2007) [18] reported that the food temperature is one of the factors that affect most on the customer satisfaction towards the quality of foods served in any institution. Author strongly suggested immediate solutions should be taken as soon as possible by those directly responsible on operations and cafeterias' operators should pay more attention regard the temperature, texture and freshness of food serve to avoid any unbearable consequences.

Despite the result from the study of Pettijohn (1997) [17] indicated that quality of food is significantly more important than any other cleanliness, price and convenience which ranked second, fourth and fifth, result from a National Restaurant Association survey (1994) [19] showed that outstanding service has always been fundamental to retain customer of all the other attributes. Nevertheless, further studies in primary health care food service establishment still need to be conducted to determine the direct relationship between them. Service quality was one of the important factors the respondents looked at when dining in a cafeteria. Many studies [15], [19]-[20] have quoted the importance of service quality in determining customer satisfaction. According to Gronroos (1990) [21], service quality is defined as the overall difference between a delivered service experiences conform to the client's expectations. It means customers perceived the quality of foodservice from their evaluation of how are they to be served in a dining cafeteria. The result from the measurement of quality service capable capturing of those tangible factors which is difficult to evaluate prior to purchase and consumption unless those elements have been experienced by the consumer. Nowadays, consumers pursue tangible indications (e.g. table cloths, utensils) in order to predict their satisfaction on food service operation [22]. Kim et al. (2009) [6] and Soriano (2002) [23], in their studies indicated that service quality was the second most important attribute in affecting student satisfaction and revisit intention. Nevertheless, none of the any above studies concluded which factor under this category could likely cause any patron dissatisfaction. Further studies in cafeteria food service establishment still need to be conducted to determine the direct relationship between them. Our study revealed that that among all the attributes in service quality, majority of the respondents were satisfied with the hygiene of staffs $(\mathrm{M}=2.51)$ and sufficiency of eating utensils $(\mathrm{M}=2.57)$ in cafeteria but the efficiency of beverage preparation $(M=2.49)$, cleanliness of eating utensil $(M=2.45)$ and friendliness of staffs $(M=2.45)$ were unacceptable.

Ambience or popularly known as operating physical environment is one of the crucial attributes in retaining customer to dine at the usual-cafeteria. In fact, Bitner (1992) [24] defined physical environment includes a comprehensive dimension on all intangible nature of services in a dining facility such as noise, music, scent, lighting and temperature, and spatial layout and all these would have an effect on customer satisfaction. Nowadays, customers are likely to spend their time and money in an establishment where the ambience prompts a feeling of pleasure [8]. With that, researcher predicted that the demand of comfortable physical environment at dining facilities from now to future would be on an upward trend [23]. Interesting fact from the study conducted by Choi et al. (2008) [25] stated that cafeteria's environmental settings such as lights and fan could actually motivate the customers to return and also their level of satisfaction. Similar notion also noted in the finding from Hensley (2007) [26] and Pun (2001) [27]. On the contrary, result reported from our finding expressed that majority of the respondents were least satisfied with the facilities $(M=2.35)$ provided in the cafeterias especially hand basin, fan, light, and hand dryer, besides comfortable at the dining area $(\mathrm{M}=2.44)$ and arrangement of dining space $(M=2.44)$. Nevertheless, our result revealed that convenience location $(M=2.66)$ was actually ranked as the most satisfied factor under ambience attributes and followed by dining layout arrangement $(M=2.63)$. The reason is because the current location of cafeteria was located at the center of the whole Klinik Kesihatan Bintulu and has a spine corridor and one layer lift linking all four sides to Pejabat Kesihatan Bahagian Bintulu, Dental Clinic, Unit of Rehabilitation and Inspectoral. Klassen et al. (2005) [28], who studied food service also, agreed that that most customers would want dining facilities near their residence office regardless the sources or type of operator. 
According to Yuksel et al. (2002) [8], price could be one of the determinants that influence the customers to revisit a dining institution. Klassen et al. (2005) [28] even stated that that price is the most important criterion when making food purchase decision and most customers would tend to dine at a place which held promotion or discounted menu item. In our context, the most likely reason is because customers especially patients who came into government Klinik Kesihatan are a group of customers who might has burden of financial income, so price is still the main concern for them generally. This is very truth in Bintulu context, as Bintulu is still considered as a district area and mostly residence here are aborigine people who financial stability might not be as strong as town dwellers. Therefore, our finding indicated majority of the respondents were not satisfied with the price $(\mathrm{M}=$ $2.25)$ and portion $(\mathrm{M}=2.20)$ of the food provided. It is cleared that polyclinic foodservice operators as well as food service policy maker should revise the pricing and portion of food packed in order to enhance customers' satisfaction, prevent them from starving or fasting during visit to the clinic or even switching to other off-institution cafeteria [6]. In fact, author aware that there is a list of pricing for each menu items pasted on the wall of purchasing area.

Next, the results also revealed that the staffs and patients showed significant difference on the satisfaction level towards the all four attributes of food ( $p>0.0)$, service $(p>0.0)$, ambience $(p>0.0)$ quality and price and portion ( $p>0.0)$ attributes. Patients were inclined toward satisfaction on food, service and ambience quality; however, both showed dissatisfaction on price and portion attributes. In our contextual setting, the most probably reason could be due to staffs are the primary customers in the primary health care setting as most of the health care worker sandwiched against their daily work and time, therefore, they have to rely on the food service operator. In contrast, patients were much more flexible and they could go off to other setting for their dining purpose. Besides, staffs could have a higher demanding in term of nutritious and quality food compared with patients. Although the findings showed patients and staffs do have a significant difference when come into the first three attributes in our context, it may not hold true when similar studies assessing satisfaction were done on different groups of customer at different setting on different state of a country [29]. Further investigations are required before a coherent conclusion can be reached.

By looking at the percentage score of three supplementary factors, majority of customers explicitly expressed that introducing the menu of the day (61\%) was their favorite concern to improve their satisfaction. The most likely reason is because customers especially staffs and regular follow up patients can be easily get bored by serving the same menu offering at the same cycle [30]. Besides, Malaysia is a diverse culture and ethnicity country which contribute to a variety of food choices, Malaysian were so used to enjoy a variety of foods, with the infusion of western foods culture, Malaysian has become a meeting place for both eastern and peninsular Malaysia culinary. Therefore, customers are always expected some degree of flexibility on food choices in their cafeteria. Another reason was because these special menus may somehow create disparity on their daily boring meals and create certain expectation in dining at their respective campus cafeteria. Recently, some institutions have revealed that introducing innovative daily special menus would actually have an impact on customer satisfactions [28].

The addition of this part from this study revealed that variability of menu (29\%) was the most likely factor that could improve the satisfaction level among staffs and patients. University management is advisable taking into account of diverse cultural and authentically ethnic of their customers when increasing food variety in order to develop a suitable and appropriate menu for the polyclinic cafeteria [31].

The following (25\%) supplementary factors were followed by "introduce franchise outlet". The score might suggest that the patients and staffs would want a diverse cuisine selection that is made up from different provider. The preference for franchise food outlet by them may be due to the influence of their reputation, consistency, quality, profitability, palatability, availability and convenience [9] [32]-[35]. In Malaysia, food chain outlet in Klinik Kesihatan or hospital cafeteria is no longer a novel matter. Tertiary health centres such as Hospital Pantai Kuala Lumpur and Gleneagles Hospital Kuala Lumpur; they have already contracted their caterer contract to Sodexo, a private branded food service operator and Starbucks respectively since few years back [10].

Judging by the result above, if the unacceptable factors from all the attributes continuously ignored by the food service operators, patients and staffs as the end probably will not frequently dine at the cafeteria and seeking other alternatives such as prepare their own food from home or dine at other institution cafeterias. For the operators, they will keep losing them as their customer and this in turn will affect the sustainability of their business. 


\section{Limitations}

This study was done on a primary health care setting in Bintulu, Sarawak. The results of the study might not represent the overall satisfaction level of patients and staffs on the other cafeteria services from Peninsular Malaysia. Besides, previous study by Yuksel et al. (2002) [8] found that most of the satisfaction study measured the level of satisfaction relative to a concept or a standard. The standards exit did not provide fair comparison when used in different situations. Different forms of service standards had been proposed in the marketing and consumer behavior literature; with the exception of predictive expectations. Similarly, in this situation, as service standards adopted in this study were originally from KKM, Ministry of Health, Hospital, Malaysia it might not be very useful in primary health care setting. However, the author believes that the use of other similar service standards may still yield similar response.

\section{Conclusion and Implication}

As the perceptions on importance of customer satisfaction have grown in the business world, studies on customer satisfaction have no longer been limited in commercial restaurant setting, but in institutional primary health care establishment. This study determined the customer satisfaction based on the Institutional DINESERV Dimension which revealed that the food, service, ambience and price and portion attributes were the major contributors of dissatisfaction in Polyclinic Bintulu cafeteria among staffs, nevertheless the food, service, ambience quality, price and portion incline towards satisfaction only among patients. Both groups revealed that price and portion are the major contributors of dissatisfaction in Klinik Kesihatan Bintulu cafeteria. The negative impressions on these attributes have given significant impact not only to patients and staffs, but also to the operators and Klinik Kesihatan Bintulu as a whole. Patients and staffs probably will decide to find alternative dining unit for their long-term basic needs. For the operators, they will probably start losing customers as their business sustainability and profit will be affected if operators continuously ignore the poor services especially in terms of price and portion in their cafeteria.

It is important this result provides a good implications to the food service operators that immediate solutions should be taken by those directly responsible on the overall operations of the cafeteria. The cafeteria operators should pay more attention to customer dissatisfaction. It is suggested the Divisional Health Officer has the right to terminate their services or issue stern warnings to the operators if food service operators are unable to provide the acceptable four attributes: food beverages, services, operating environment, price and portion in their dining unit or cafeteria according to the existing cafeteria guidelines developed by Division of Nutrition and Food Safety. A better stringent screening test must be carried out by officers in charge, not only by looking at the ability and experience of the operators, but also by referencing their performance with other food service operators in similar setting when it comes to the point to renew their contract or services. Hence, patients and staffs will not only feel comfortable during their visiting and working in Klinik Kesihatan Bintulu, but also provide nutritious and quality food as well as good dining experience which is crucial for patients and staffs to excel in their recovery and working performance.

\section{Conflict of Interest Statement}

The authors declare that they have no competing interest.

\section{References}

[1] Sivasampu, S., Yvonne, L. and Norazida, A.R. (2014) National Medical Care Statistics (NMCS) 2012. National Clinical Research Centre, Kuala Lumpur.

[2] Borneo Post (2010) RM26 mln to Promote Polyclinic. http://www.theborneopost.com/2010/11/16/rm26-mln-polyclinic/

[3] Liang, X. and Zhang, S. (2009) Investigation of Customer Satisfaction in Student Food Service: An Example of Student Cafeteria in NHH. International Journal of Quality and Service Sciences, 1, 113-124.

[4] Gramling, L., Byrd, R., Epps, L. and Keith, D. (2005) Foodservice Management and Its Impact on College Operations: A Business Anthropological Case Study. Foodservice Research International, 16, 15-43.

[5] Drummond, K.E. and Brefere, L.M. (2001) Nutrition for Foodservice and Culinary Professionals. 4th Edition, John Wiley and Sons, Inc., New Jersey. 
[6] Kim, W.G. and Kim, Y.S. (2009) Influence of Institutional DINESERV on Customer Satisfaction, Return Intention, and Word-of-Mouth. International Journal of Hospitality Management, 28, 10-17.

[7] Oh, H. (2000) Diners’ Perception of Quality, Value, and Satisfaction: A Practical Viewpoint. Cornell Hotel and Restaurant Administration Quarterly, 41, 58-66.

[8] Yuksel, A. and Yuksel, F. (2002) Measurement of Tourist Satisfaction with Restaurant Services: A Segment-Based Approach. Journal of Vacation Marketing, 9, 52-68.

[9] Green, C.G. (1994) Nutrition Awareness and Branding in College/University Food Services: What Motives These Trends? Journal of College \& University Food Service, 2, 39-58.

[10] Gleneagles Kuala Lumpur (2014) Retail Services. http://gleneagleskl.com.my/patient-info/retail-services/

[11] Pejabat Kesihatan Bahagian Bintulu Sarawak (2014) Registration Database Report. Department of Registration Counter.

[12] Krejcie, R. and Morgan, D.W. (1970) Determining Sample Size for Research Activities. Educational and Psychological Measurement, 30, 607-610.

[13] Nunnally, J.C. (1978) Psychometric Theory. 2nd Edition, McGraw-Hill, New York.

[14] Pettijohn, L.S., Pettijohn, C.E. and Luke, R.H. (1997) An Evaluation of Fast Food Restaurant Satisfaction: Determinants, Competitive Comparisons, and Impact on Future Patronage. Journal of Restaurant \& Foodservice Marketing, 2, 3-20. http://dx.doi.org/10.1300/J061v02n03_02

[15] Qu, H. (1997) Determinant Factors and Choice Intention for Chinese Restaurant Dining: A Multivariate Approach. Journal of Restaurant \& Foodservice Marketing, 2, 35-49. http://dx.doi.org/10.1300/J061v02n02_03

[16] Mattila, A.S. (2001) Emotional Bonding and Restaurant Loyalty. Cornell Hotel and Restaurant Administration Quarterly, 42, 73-79. http://dx.doi.org/10.1016/S0010-8804(01)81012-0

[17] Kim, S.R. (2005) Information System and Improvement Device of School Food Services. Master's Thesis, The Graduate School of Kumho University, Gyeongbuk.

[18] Namkung, Y. and Jang, S. (2007) Does Food Quality Really Matter in Restaurants? Its Impact on Customer Satisfaction and Behavioral Intentions. Journal of Hospitality \& Tourism Research, 31, 387-409. http://dx.doi.org/10.1177/1096348007299924

[19] National Restaurant Association (1992) Restaurant Industry Operations Report. Washington DC.

[20] Stevens, P., Knutson, B. and Patton, M. (1995) Dineserv: A Tool for Measuring Service Quality in Restaurants. Cornell Hotel and Restaurant Administration Quarterly, 36, 56-60. http://dx.doi.org/10.1177/001088049503600226

[21] Gronroos, C. (1990) Service Management and Marketing: Managing the Moments of Truth in Service Competition. Lexington Books, Lexington.

[22] Ryu, K., Han, H. and Kim, T.H. (2008) The Relationships among Overall Quick-Casual Restaurant Image, Perceived Value, Customer Satisfaction and Behavioural Intentions. International Journal of Hospitality Management, 27, 459469. http://dx.doi.org/10.1016/j.ijhm.2007.11.001

[23] Soriano, D.R. (2002) Customers' Expectations Factors in Restaurants: The Situation in Spain. International Journal of Quality and Reliability Management, 19, 1055-1067. http://dx.doi.org/10.1108/02656710210438122

[24] Bitner, M.J. (1992) Servicescapes: The Impact of Physical Surroundings on Customers and Employees. Journal of Marketing, 56, 57-71. http://dx.doi.org/10.2307/1252042

[25] Choi, J.K., Silkes, C.A. and Adler, H. (2008) An Examination of Consumer Behaviour in Restaurant Wine Purchases. Proceedings of 2008 Euro Council on Hotel, Restaurant and Institutional Education Annual Conference (EUROCHRIE), Dubai, 11-14 October 2008.

[26] Hensley, R.L. and Sulek, J. (2007) Customer Satisfaction with Waits in Multi-Stage Services. Managing Service Quality, 17, 152-173. http://dx.doi.org/10.1108/09604520710735173

[27] Pun, K.F. and Ho, K.Y. (2001) Identification of Service Quality Attributes for Restaurant Operations: A Hong Kong Case. Managing Service Quality, 11, 233-240. http://dx.doi.org/10.1108/09604520110397940

[28] Klassen, K.J., Trybus, E. and Kumar, A. (2005) Planning Food Services for a Campus Setting. International Journal of Hospitality Management, 24, 579-609. http://dx.doi.org/10.1016/j.ijhm.2005.01.001

[29] Adams, S.A. (1997) Socioeconomic Effects on College Student Food Consumption and Satisfaction Levels Based on Choices Available. Journal of College \& University Foodservice, 3, 63-72. http://dx.doi.org/10.1300/J278v03n03_05

[30] Ghani, F.A. and Zahari, M.S.M. (2011) Service at UITM Residential Hostel Cafeterias-Is It Satisfactory? World Applied Sciences Journal, 12, 8-13.

[31] Schuster, K. (2007) Making It Authentic, Making It Ethnic. Food Management, 42, 42-52.

[32] Bernstein, C. (1991) Mufso Pioneer: Chick-fil-A Founder Cathy. Nation’s Restaurant News, 1. 
[33] Muller, C. (1998) Endorsed Branding. The Next Step in Restaurant-Brand Management. Cornell Hospitality Quarterly, 39, 90-96. http://dx.doi.org/10.1177/001088049803900317

[34] Yahia, N., Achkar, A., Abdallah, A. and Rizk, S. (2008) Eating Habits and Obesity among Lebanese University Students. Nutrition Journal, 7, 32. http://dx.doi.org/10.1186/1475-2891-7-32

[35] Gan, W.Y., Mohd, N.M., Zalilah, M.S. and Hazizi, A.S. (2011) Differences in Eating Behaviours, Dietary Intake and Body Weight Status between Male and Female Malaysian University Students. Malaysian Journal of Nutrition, 17, 213-228. 